JАВНО ЗДРАВЈЕ

\title{
ТОКСИЧНИ ЕЛЕМЕНТИ ВО ОРИЗ, ПЧЕНИЧНО БРАШНО И ПРОИЗВОДИ ОД БРАШНО ОД МАКЕДОНСКИОТ ПАЗАР
}

\author{
Надица Тодоровскаํㅡ, Сузана Диневска Ќовкаровска², Орце Поповски³, Елисавета Стикова4

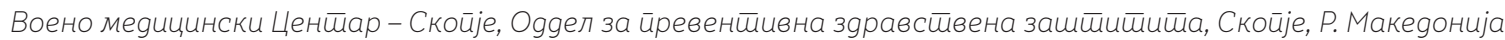

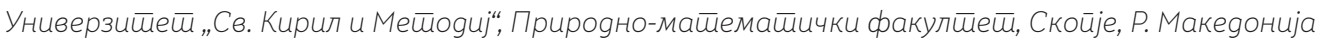

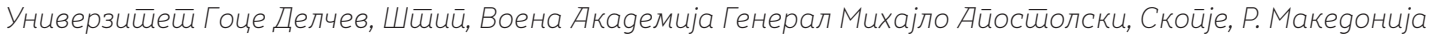

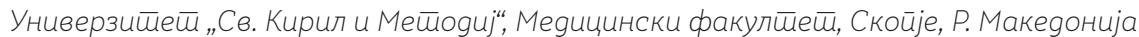

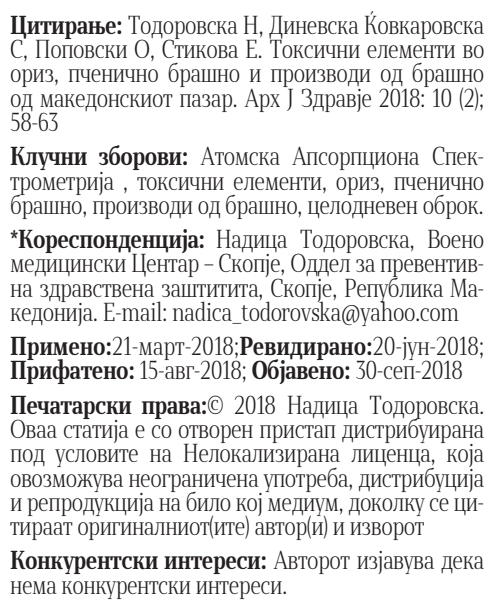

\section{Извадок}

Безбедноста на житата и житните производи е од големо нутритивно и токсиколошко значење, бидејќ житната индустрија и нејзините производи имаат голема економска и социјална важност на светско ниво. Во ова пилот истражување е испитана концентрацијата на токсичните елементи во траги арсен, кадмиум и олово, во три мостри од различни производители на ориз: 11,67+5,69 $\mu \mathrm{g} / \mathrm{kg}, 25,67+6,43 \mu \mathrm{g} / \mathrm{kg}, 47,67+18,01 \mu \mathrm{g} / \mathrm{kg}$, пченично брашно: $7+5 \mu \mathrm{g} / \mathrm{kg}, 9+1,73 \mu \mathrm{g} / \mathrm{kg}, 69,92+16,92 \mu \mathrm{g} / \mathrm{kg}$ за As, Cd и Pb, соодветно, и производи од браш-

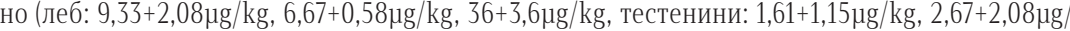
$\mathrm{kg}, 30+7 \mu \mathrm{g} / \mathrm{kg}$ и чајни колачи: $4,67+4,04 \mu \mathrm{g} / \mathrm{kg}, 1,33+0,58 \mu \mathrm{g} / \mathrm{kg}, 53+9,64 \mu \mathrm{g} / \mathrm{kg}$ за As, Cd и Pb, соодветно) од македонскиот пазар, со употреба на хидридно генерирачка и електротермичка атомска апсорпциона спектрометрија со мокра дигестија. Извршена е пресметка на учеството во просечниот дневен внес за токсични елементи внесени преку дневна консумација на жито и производи од жито (20\% од целодневниот оброк). Придонесот на As $(9,86 \%), \mathrm{Cd}(10,02 \%)$ и $\mathrm{Pb}(11,39 \%)$ спореден со просечниот дневен внес и прифатливиот толериран дневен внес, PTDI, беше низок, што покажува дека овие производи се безбедни за употреба во однос на испитаните токсични елементи. Нивоата на токсичните елементи во мострите на македонскиот ориз, пченично брашно и производи од брашно се споредливи со резултатите добиени од различни делови од светот и нивниот внес не претставува здравствен ризик за потрошувачите.

\section{PUBLIC HEALTH}

\section{TOXIC ELEMENTS IN RICE, WHEAT FLOUR AND WHEAT FLOUR PRODUCTS FROM THE MACEDONIAN MARKET}

\author{
Nadica Todorovska ${ }^{1}$, Suzana Dinevska Kjovkarovska², Orce Popovski ${ }^{3}$ Elisaveta Stikova ${ }^{4}$ \\ Military Medical Center - Skopje, Department of Preventive Health Protection, Skopje, Republic of Macedonia. Macedonia \\ University "St. Cyril and Methodius ", Faculty of Natural Sciences and Mathematics, Skopje, Republic of Macedonia \\ Goce Delcev University, Stip, Military Academy General Mihajlo Apostolski, Skopje, Republic of Macedonia \\ "University "St. Cyril and Methodius ", Faculty of Medicine, Skopje, Republic of Macedonia. Macedonia
}

\begin{abstract}
Citation: Todorovska N, Dinevska Kjovkarovska S, Popovski O, Stikova E. Toxic elements in rice, wheat flour and wheat flour products from the macedonian market. Arch Pub Health 2018: 10 (2); 58-63 (Macedonian)

Key words: oatomic absorption spectrometry, toxic elements, rice, wheat flour, flour products, all-day meal.

*Correspondence: Nadica Todorovska, Military Medical Center - Skopje, Department of Preventive Mealth Protection, Skopje, Republic of Macedonia. Macedonia. e-mail: nadica_todorovska@yahoo.com Received: 21-Mar-2018; Revised: 20-Jun-2018; Accepted: 15-Aug-2018; Published: 30-Sep-2018 Copyright:@ 2018. Nadica Todorovska. This is an open-access article distributed under the terms of the Creative Commons Attribution License, which permits unrestricted use, distribution, and reproduction in any medium, provided the original author(s) and source are credited.

Competing Interests: The author have declared that no competing interests
\end{abstract}

\section{Abstract}

The safety of the cereal products is of high nutritional and toxicological interest, since the cereal industry and its products have a big economic and social importance worldwide. In this pilot research the presence and the content of toxic trace elements arsenic, cadmium and lead in three samples of rice: $11,67+5,69 \mu \mathrm{g} / \mathrm{kg}, 25,67+6,43 \mu \mathrm{g} / \mathrm{kg}, 47,67+18,01 \mu \mathrm{g} / \mathrm{kg}$ for As, $\mathrm{Cd}$ and $\mathrm{Pb}$ respectively, wheat flour: $7+5 \mu \mathrm{g} / \mathrm{kg}, 9+1,73 \mu \mathrm{g} / \mathrm{kg}, 69,92+16,92 \mu \mathrm{g} / \mathrm{kg}$ and flour products (bread: 9,33+2,08$\mu \mathrm{g} / \mathrm{kg}$, $6,67+0,58 \mu \mathrm{g} / \mathrm{kg}, 36+3,6 \mu \mathrm{g} / \mathrm{kg}$, pasta: $1,61+1,15 \mu \mathrm{g} / \mathrm{kg}, 2,67+2,08 \mu \mathrm{g} / \mathrm{kg}, 30+7 \mu \mathrm{g} / \mathrm{kg}$ and tea biscuits: $4,67+4,04 \mu \mathrm{g} / \mathrm{kg}, 1,33+0,58 \mu \mathrm{g} / \mathrm{kg}, 53+9,64 \mu \mathrm{g} / \mathrm{kg}$ for As, Cd and Pb respectively) produced by three different manufacturers from Macedonia was determined by applying the hydride generation and electrothermal atomic absorption spectrometry with wet digestion. In this research the contribution to the average daily intake for toxic elements through daily intake of cereal and cereal products (20\% of the all-day meal) has been determined. The contribution of As $(9,86 \%)$, $\mathrm{Cd}(10,02 \%)$ and $\mathrm{Pb}(11,39 \%)$ compared to the average daily intake and the PTDI was low, which indicates that these products are safe for consumption concerning the examined toxic elements. The levels of the toxic elements in the samples of Macedonian rice, wheat flour, bread, pasta and tea biscuits are comparable to those obtained from various parts of the world and their consumption does not pose any health risks. 


\section{Вовед}

Можната контаминација на храната со тешки метали претставува сериозен јавно-здравствен проблем и се јавува почнувајќи од нејзиното производство (загадена земја, вода и воздух), преку преработката, пакувањето и складирањето, до приготвувањето за употреба. Ресорпцијата на тие елементи преку дигестивниот тракт на човекот се движи од 5 до $10 \%$, зависно од нивната концентрација во храната. Некои елементи како олово, кадмиум и арсен, пројавуваат токсични својства и во релативно ниски концентрации и имаат својство да се кумулираат во ткиватаㄹ. Од овие причини содржината на токсичните елементи во храната треба да биде под постојана контрола.

Соединенијата на арсен, кои се растворливи, се апсорбираат преку гастро-интестиналниот тракт ГИТ, белите дробови и кожата ${ }^{2}$. Арсенот претставува протоплазматски отров, а според Интернационална агенција за испитување на канцерот, IARC, припаѓa на 1 група канцерогени за човекот, внесен како неорганско соединение ${ }^{3}$.

Во човековиот организам кадмиумот се ресорбира внесен орално преку ГИТ и, потешко, внесен инхалационо преку белите дробови. Тој е високотоксичен, кумулативен, нефротоксичен отров ${ }^{4}$ кој го инхибира ензимскиот систем. Според IARC 1993 година, кадмиумот е класифициран во 1 група канцеролгени за човекот.

Оловото во човековиот организам е кумулативен, системски отров, невротоксин, особено кај децата ${ }^{5}$. Соединенијата на олово лесно се апсорбираат во организмот по пат на инхалација или орално Според IARC оловото е класифицирано во 2Б група како можен хуман канцероген.

Овие елементи, според важечките правилници во нашата земја, најчесто се испитувани во производите за исхрана и се од голема важност за следење на нивната безбедност и исправност. Биомониторингот на евентуалното покачување на концентрациите на некои од испитуваните елементи во прехранбените производи над максимално дозволените, може да биде и индикатор за потеклото на про- изводите.

Производите: ориз, пченично брашно и производи од брашно, редовно се консумираат и сочинуваат голем дел од дневниот оброк на човекот - до 45\%, според Светската здравствена организација, $\mathrm{C}^{3} \mathrm{O}^{8}$. Во житото и житните производи може да се најдат тешките метали олово и кадмиум, како и елементот арсен, кои може да потекнуваат и од загадувачи од воздухот, водата и почвата, но, и од процесот на производството на намирниците (мелење, пакување и сл.).

Во Одделот за превентивна здравствена заштита при Воено Медицинскиот Центар - Скопје, редовно се врши контрола на исправноста на прехранбените производи од македонскиот пазар кои се користат во исхраната во однос на токсични елементи. Добиените резултати за концентрациите на елементите арсен, кадмиум и олово се споредуваат со законски одредените максимално дозволени концентрации, МДК, во соодветниот прехранбен производ.

Заради потребата од редовно следење на квалитетот на прехранбените производи од домашниот пазар произлезе целта на ова пилот истражување: да се одреди концентрацијата на елементите од интерес во прехранбените производи поединечно (ориз, пченично брашно и производи од брашно) од македонскиот пазар што се консумираат во секојдневната исхрана на возрасни испитаници, да се процени придонесот на испитуваните елементи во намирниците од групата на жито и производи од жито употребени во подготовка на петодневен целодневен оброк (појадок, ужина, ручек и вечера) на одреден колектив на возрасна популација од Република Македонија и да се процени дневниот внес на тие елементи преку оваа група прехранбени производи според прифатливиот толериран дневен внес, PTDI 9,10,11.

\section{Материјал и методи}

Во текот на ова пилот истражување испитувани се по една мостра од три различни прехранбени производи од производители од РМ и одредена е концентрација на елементите арсен, кадмиум и олово во мостри од жито (ориз), пченично брашно 
и производи од брашно (леб, тестенини и чајни колачи) кои се пуштени во промет како здравствено безбедни и се користат во секојдневната исхрана на населението на PM.

Овие производи се употребени во исхраната на еден колектив возрасни испитаници од РМ при приготвување на целодневни оброци во текот на пет дена. Според рецептурите за приготвување на оброците: доручек, ужина, ручек и вечера, пресметано е учеството на оваа група производи (жито и производи од жито) во целодневните оброци за пет дена, а според тоа е пресметан и просечен дневен внес на елементите од интерес во целодневниот оброк кој е спореден со прифатливиот толериран дневен внес, PTDI, за секој елемент ${ }^{9,10,11}$.

Мострите се подготвуваат за анализа со мокро разложување со оксидациско средство на соодветна температура и се преведуваат во раствор. Измереното количество мостра од производот се префрла во соодветен сад со концентрирана азотна киселина $(69 \%, \mathrm{~m} / \mathrm{V})$ и се остава да стои 24 часа покриено со саатно стакло. Потоа, се загрева до 100оС до целосно одвојување на азотните оксиди, до бел талог, со повремено додавање на концентрирана азотна киселина $(69 \%, \mathrm{~m} / \mathrm{V})(1-2$ $\mathrm{mL})$.

Во прехранбените производи се определени концентрациите на елементите: олово и кадмиум со електротермичка атомска апсорпциона спектрометрија, ETAAC, а на елементот арсен со хидридно генерирачка атомска апсорпциона спектрометрија, ХГААС. Границите на детекција на користените техники се: за арсен 0,5 $\mu \mathrm{g} / \mathrm{L}$ (VGA 77), за кадмиум 0,1 $\mu \mathrm{g} / \mathrm{L}$ и за олово $0,6 \mu \mathrm{g} / \mathrm{L}$ (Varian SpectrAA $220 \mathrm{Z})$.

Методата на калибрација е со мостра на која претходно е додаден стандарден додаток $^{12}$.

\section{Резултати}

Во табела 1. се прикажани добиените резултати од испитувањето на три мостри на ориз, пченично брашно, и производи од брашно (леб, тестенини и чајни колачи), од различни производители од РМ, кои се употребени во текот на пет дена во подготовката на целодневните оброци на колективот.

\begin{tabular}{|l|c|c|c|c|}
\hline Прехранбен производ & Број на мостри & As & $\mathbf{C d}$ & $\mathbf{P b}$ \\
\hline Ориз & 3 & $11,67+5,69$ & $25,67+6,43$ & $47,67+18,01$ \\
\hline Брашно пченично & 3 & $7+5$ & $9+1,73$ & $69,92+16,92$ \\
\hline Леб бел & 3 & $9,33+2,08$ & $6,67+0,58$ & $36+3,6$ \\
\hline Тестенини & 3 & $1,61+1,15$ & $2,67+2,08$ & $30+7$ \\
\hline Чаен колач & 3 & $4,67+4,04$ & $1,33+0,58$ & $53+9,64$ \\
\hline
\end{tabular}

Табела 1: Средна вредност на концентрациите на елементите во испитуваните прехранбени производи со стандардни девијации во $\mu \mathrm{g} / \mathrm{kg}$

Концентрацијата на елементите во секоја мостра варира во зависност од одгледувањето, производството, пакувањето на производот и слично. Во трите мостри на ориз од македонскиот пазар измерени се концентрации на арсен од 7 до $18 \mu \mathrm{g} / \mathrm{kg}$, на кадмиум од 21 до $33 \mu \mathrm{g} / \mathrm{kg}$, а на олово од 27 до $60 \mu \mathrm{g} /$ $\mathrm{kg}$. Во мострите на пченично брашно измерени се концентрации на арсен од 2 до $12 \mu \mathrm{g} / \mathrm{kg}$, на кадмиум од 8 до $11 \mu \mathrm{g} /$ $\mathrm{kg}$ и олово од 55 до $88 \mu \mathrm{g} / \mathrm{kg}$. Во мострите на бел леб од 7 до $11 \mu \mathrm{g} / \mathrm{kg}$ арсен, од 6 до $7 \mu \mathrm{g} / \mathrm{kg}$ кадмиум и од 33 до $40 \mu \mathrm{g} / \mathrm{kg}$ олово, додека во мострите на тестенини од 0,1 до $2 \mu \mathrm{g} / \mathrm{kg}$ арсен, од 1 до $5 \mu \mathrm{g} /$ $\mathrm{kg}$ кадмиум и од 23 до $37 \mu \mathrm{g} / \mathrm{kg}$ олово, а во мострите на чајни колачи од 0,1 до 7 
$\mu \mathrm{g} / \mathrm{kg}$ арсен, од 1 до $2 \mu \mathrm{g} / \mathrm{kg}$ кадмиум и од 42 до $57 \mu \mathrm{g} / \mathrm{kg}$ олово.

За да се согледа здравствениот ризик на потрошувачите, потребно е да се направи проценка на внесот на елементите од интерес преку секојдневната исхрана и да се спореди со токсиколошки прифатливите нивоа. Според рецептурите за подготовка на оброците, сите употребени производи беа поделени во групи и се пресмета дека групата жито и производи од жито е застапена просечно со $20 \%$ од вкупно користените прехранбени производи во подготовка на целодневниот об- рок - појадок, ужина, ручек и вечера, за пет дена на испитаната популација со колективна исхрана од РМ.

Во табела 2. е прикажан придонесот на испитуваните елементи во прехранбените производи од групата на жито и житни производи кои се употребени во подготовка на петодневниот целодневен оброк, во однос на вкупното количество на елементите во оброците. Од добиените вредности е пресметан просечниот дневен внес на испитуваните елементи преку храна и е спореден со пропишаните норми од СЗО за PTDI.

\begin{tabular}{|c|c|c|c|}
\hline Испитувани елементи & As & Cd & $\mathrm{Pb}$ \\
\hline $\begin{array}{l}\text { Пресметан дневен внес на еле- } \\
\text { ментите преку целодневен оброк } \\
\text { во } \mu \mathrm{g}\end{array}$ & 37,6 & 34,6 & 220,6 \\
\hline $\begin{array}{l}\text { Пресметан дневен внес на елемен- } \\
\text { тите преку групата жито, брашно } \\
\text { и производи од брашно (20\%) }\end{array}$ & $\begin{array}{c}4,334 \mu g \\
(9,86 \%)\end{array}$ & $\begin{array}{l}3,62 \mu g \\
(10,02 \%)\end{array}$ & $\begin{array}{l}25,49 \mu g \\
(11,39 \%)\end{array}$ \\
\hline 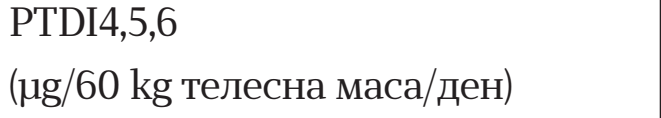 & 128 & 60 & 214 \\
\hline
\end{tabular}

Табела 2: Пресметан дневен внес на испитуваните елементи преку намирниците од жито (ориз), и производи од жито (пченично брашно и производи од брашно) во целодневниот оброк во однос на пропишани норми PTDI

Во табелата е внесено учеството на групата жито, брашно и производи од брашно со 20\% од оброкот, додека придонесите на секој елемент засебно во употребените производи, прикажани во загради, не го надминуваат овој процент. Имено, дневниот внес на арсен преку оваа група производи е 4,334 $\mu \mathrm{g}$ што претставува 9,86\% од пресметаниот дневен внес на овој елемент преку целодневниот оброк. Дневниот внес на кадмиум од групата на жито и производи од жито е $10,02 \%$, додека на олово е 11,39\%. Исто така пресметаниот дневен внес за секој елемент преку целодневниот оброк не ги надминува нормите за PTDI.

\section{Дискусија}

Елементите арсен, кадмиум и олово се токсични и во ниски концентрации може да бидат штетни по човековото здравје.
Тие, преку почвата, водата и воздухот, може да се акумулираат во растенијата и животните што се користат во секојдневна исхрана. Така човековото здравје може да биде загрозено преку консумација на прехранбените производи загадени со овие токсични елементи.

Добиените резултатите од ова пилот истражување за концентрациите на елементите од интерес во испитуваните производи од групата на жито и производи од жито се во согласност со нормите од Правилникот за општи барања за безбедност на храна ${ }^{8}$ и се споредливи со резултатите од цитираната литература од повеќе региони. Во трите мостри на ориз е најдена концентрација на кадмиум (МДК за ориз до $200 \mu \mathrm{g} / \mathrm{kg}$, за житарки до 100 $\mu \mathrm{g} / \mathrm{kg}$ ) и на олово (МДК $200 \mu \mathrm{g} / \mathrm{kg}$ за житарки) која е во границите на МДК според правилниците $\mathrm{e}^{13,14,15}$. Во литературата се наведени слични вредности за арсен, 
кадмиум и олово (во ориз од Иран: As

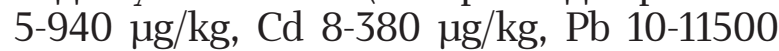

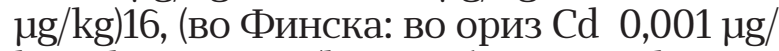

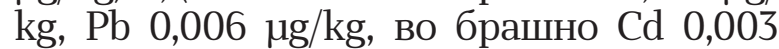
$\mu \mathrm{g} / \mathrm{kg}, \mathrm{Pb} 0,009 \mu \mathrm{g} / \mathrm{kg}$, во леб Cd 0,003 $\mu \mathrm{g} /$ $\mathrm{kg}, \mathrm{Pb} 0,008 \mu \mathrm{g} / \mathrm{kg}$, во тестенини Cd 0,005 $\mu \mathrm{g} / \mathrm{kg}, \mathrm{Pb} 0,004 \mu \mathrm{g} / \mathrm{kg}$ )17, (во ориз од Италија $\mathrm{Cd}$ 0,025 $\mu \mathrm{g} / \mathrm{kg}, \mathrm{Pb} 0,02 \mu \mathrm{g} / \mathrm{kg}$ )18, (во ориз од Нигерија Cd 5,43+0,88 $\mu \mathrm{g} / \mathrm{kg}$ и $\mathrm{Pb} 38,66+5,48 \mu \mathrm{g} / \mathrm{kg}$ )19, (во ориз од Шпанија и Португалија As 0,17+0,06 mg/ $\mathrm{kg} \mathrm{Cd}$ 0,011+0,01 mg/kg Pb 0,003+0,002 mg/kg)20, (во ориз од Шведска As 0,02 mg/kg, Cd 0,024mg/kg, Pb 0.004mg/kg)21, (во пченично брашно од Ирак Cd 0,08-0,09 mg/kg, Pb 0,3-0,35 mg/kg, бел леб Cd 0,07-0,15 mg/kg $\mathrm{Pb} 0,33-0,48 \mathrm{mg} / \mathrm{kg}) 22$.

Резултатите од пресметките на внесот на елементите од интерес преку секојдневната исхрана преку сите прехранбени производи употребени во подготовка на целодневен оброк и резултатите од проценката на внесот само преку прехранбените производи од групата жито и производи од жито покажуваат дека внесот на елементите преку оваа група е понизок од 20\%, колку што изнесува процентот на учество на оваа група производи во целодневниот оброк. Тоа укажува на квалитетот на производите од групата и нивната здравствена исправност. Добиените резултати се споредија со токсиколошки прифатливите нивоа PTDI $(\mu \mathrm{gg} / 60 \mathrm{~kg}$ телесна маса/ден) за арсен ${ }^{4}$, кадмиум ${ }^{5}$ и олово6 и се покажа дека се пониски во однос на арсен и кадмиум, а во согласност (3\% повисок од PTDI) во однос на олово, имајќи предвид дека испитаниците опфатени со колективната исхрана испитувана во ова истражување имаат поголема просечна телесна маса од $60 \mathrm{~kg}$.

\section{Заклучок}

Испитаните прехранбени производи од групата жито и производи од жито од македонскиот пазар, во однос на концентрациите на испитуваните елементи, се здравствено исправни. Добиените вредности во ова пилот истражување, за трите елементи во секој прехранбен производ: ориз 11,67+5,69 $\mu \mathrm{g} / \mathrm{kg}, 25,67+6,43 \mu \mathrm{g} /$ $\mathrm{kg}, 47,67+18,01 \mu \mathrm{g} / \mathrm{kg}$, и пченично брашно: $7+5 \mu \mathrm{g} / \mathrm{kg}, 9+1,73 \mu \mathrm{g} / \mathrm{kg}, 69,92+16,92 \mu \mathrm{g} / \mathrm{kg}$ за $\mathrm{As}, \mathrm{Cd}$ и $\mathrm{Pb}$, соодветно, и производи од

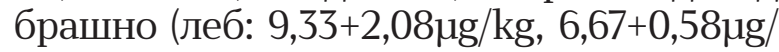

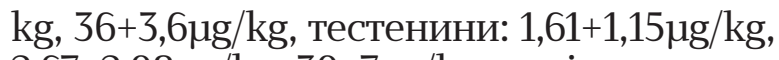
$2,67+2,08 \mu \mathrm{g} / \mathrm{kg}, 30+7 \mu \mathrm{g} / \mathrm{kg}$ и чајни колачи: $4,67+4,04 \mu \mathrm{g} / \mathrm{kg}, 1,33+0,58 \mu \mathrm{g} / \mathrm{kg}, 53+9,64 \mu \mathrm{g} /$ $\mathrm{kg}$ за As, Cd и $\mathrm{Pb}$ соодветно) се во согласност со вредностите од литературата добиени за слични житни производи од различни региони во светот16-22.

Пресметаниот придонес на оваа група производи во дневниот внес на $\mathrm{As}, \mathrm{Cd}$ и $\mathrm{Pb}$ на PTDI изнесува: 9,86\% за арсен, $10,02 \%$ за кадмиум и 11,39\% за олово, и е понизок во однос на застапеноста на групата жито и производи од жито во целодневниот оброк со 20\%, што укажува на нивна безбедност при користењето во подготовка на целодневните оброци на населението на РМ. Дневниот внес на испитуваните елементи преку целодневен оброк е во границите на токсиколошки прифатливите нивоа што укажува на високиот кавалитет на оброците на овој колектив во однос на концентрацијата на токсични елементи.

\section{Референци}

1. Beckett W. S, Nordberg G. F, Clarkson T. W. Routes of exposure, dose and metabolism of metals. Sevier Amsterdam-Tokyo. 2007: 39-76.

2. ATSDR Toxicological Profile for Arsenic ATSDR. The Agency for Toxic Substances and Disease Registry. DHHS 2000: 132.

3. Kristiforović-Ilić M. Komunalna higiena. Novi Sad: Prometej; 1998. ISBN 86-7639-366-4

4. Nordberg G. F, Fowler B. A, Nordberg M. Handbook on the Toxicology of Metals. Third Edition. Burlington: Academic Press; 2007. In: WHO. Human biomonitoring: facts and figures. Copenhagen: WHO Regional Office for Europe. 2015.

5. Andersen H. R, Nielsen J. B, Grandjean P. Toxicologic evidence of developmental neurotoxicity of environmental chemicals. Toxicology. Odense, Denmark: Department of Environmental Medicine, Odense University; 2000: 144(1-3):121-127.

6. Emsley J. Nature‘s Building Blocks: 
An A-Z Guide to the Elements. Oxford University Press; 2011. ISBN 9780-19-960563-7.

7. Caruso J.A. et al. Group assessment: Elemental speciation. Ecotoxicology and Environmental Safety. 2003: 56: 32-44.

8. WHO. CINDI dietary guide 2000. ISBN 9289011831

9. FAO/WHO Technical Report Series 776 Evaluation of Certain Food Contaminants: A Sixty-fourth report of the Joint FAO/WHO Expert Committee on Food Additives JECFA. 2006.

10. FAO/WHO Technical Report Series 930 Evaluation of Certain Food Contaminants: A Sixty-fourth report of the Joint FAO/WHO Expert Committee on Food Additives JECFA 33/27. 2011 .

11. FAO/WHO Technical Report Series 896 Evaluation of Certain Food Contaminants: A Sixty-fourth report of the Joint FAO/WHO Expert Committee on Food Additives JECFA 53/81. 2011b.

12. Barbosa R, Silvade Paula E, Paulelli A, Moore A, Oliveira Souza J, Batista B, Campiglia A, Barbosa Jr F. Recognition of organic rice samples based on trace elements and support vector machines. Journal of Food Composition and Analysis. 2016 (45): 95-100

13. Правилник за општи барања за безбедност на храната во однос на максимални нивоа на одделни компоненти, Сл.В. РМ бр.102/2013

14. Правилник за општи барања за безбедност на храната Сл. В. на РМ бр. 118/2005

15. Commission Regulation (EC) No 1881/2006 of 19 December 2006 setting maximum levels for certain contaminants in foodstuffs. Official journal of European Union L 111/3, br. 420/2011.

16. Chaleshtori FS, Kopaei MR, Chaleshtori RS. A review of heavy metals in rice (Oryza sativa) of Iran. Toxin Review 2016; 36 (2): 147-53.
17. Ekholm P, Reinivuo $\mathrm{H}$, Mattila $\mathrm{P}$, Pakkala H, KoponenJ, Happonen A, Hellstrom J, Ovaskainen M. Changes in the mineral and trace element contents of cereals, fruits and vegetables in Finland. J of Food Composition and Analysis 2007; 20: 487-95

18. Brizio P, Benedetto A,Squadrone S,Curcio A,Pellegrino M, Ferrero M, Abete M. Heavy metals and essential elements in Italian cereals. Food Additives \& Contaminants: Part B Surveillance 2016; (9): 4: 261-267.

19. Adedire C,Adeyemi J,Paulelli A, Da CunhaMartins-Jr.A, Ileke K, Segura F, De Oliveira-Souza V, Batista B, Barbosa Jr F. Toxic and essential elements in Nigerian rice and estimation of dietary intake through rice consumption. Food Additives \& Contaminants: Part B Surveillance 2015; (8): 4: 271-276.

20. Pinto E, Almeidab A, Ferreiraa I. Essential and non-essential/toxic elements in rice available in the Portuguese and Spanish markets. Journal of Food Composition and Analysis 2016; (48): 81-87

21. Jorhem L, Åstrand C, Sundström B, Baxter M, Stokes P, Lewis J. Elements in rice from the Swedish market: Part 1. Cadmium, lead and arsenic (total and inorganic). Food Additives \& Contaminants: Part A. 2008 (25): 3: 284-92.

22. Jawad I, Allafaji S. The levels of Trace Metals Contaminants in Wheat Grains, Flours and Breads in Iraq. Australian Journal of Basic and Applied Sciences, 2012(10): 6: 88-92.ISSN 1991-8178 